\title{
Podcast Effects on EFL Learners' Listening Comprehension
}

\author{
Abdul Rahman \\ rahmanabd716@gmail.com \\ Haryanto Atmowardoyo \\ haryanto@unm.ac.id \\ Kisman Salija \\ kismansalija@unm.ac.id \\ State University of Makassar
}

\begin{abstract}
Undoubtedly the Internet sources are absolutely beneficial to the senior high school students since they carried the target language together in itself. The present study aimed to explore podcast effects on EFL learners' listening comprehension. This study involved sixty students chosen from the eleventh grade students of the science department at SMU Negeri 1 luwu in 2017/2018 academic years. They divided into two groups, namely the experimental and control group. The listening comprehension test and the open-ended questions administered to fulfil the objectives of the study. The quantitative data were analysed by utilizing paired and independent samples t-test, and the qualitative data was analysed through an open coding technique by identifying, naming, and describing the phenomena of the gathered data. The quantitative results indicated that the use of podcast was more effective than the use of non-podcast. It was proven by the value of the mean score from both of the groups $(53.73>37,46)$. The different $(\mathrm{df})$ of those two mean scores was statistically significant based on the the $t$ - test value at 0.05 significance level. The probability value was smaller than significant level $(0.000<0.05)$. In other words, the result of hypothesis testing found that t-value $=4.791$ was higher than t-table $=2.000$ $(\mathrm{p}=0.05, \mathrm{df}=58)$. Ha was accepted and Ho was rejected. In addition, the result of openended question analysis highlighted that podcast was attractive in the teaching and learning of English as a foreign language listening comprehension.
\end{abstract}

Keywords: Podcast, Listening Comprehension, Learning Interest

\section{INTRODUCTION}

Vast amounts of literature claim that the success of the teaching and learning language lay on listening. It is because when people learn language some $40 \%$ of their time was spent in listening. Listening, providing an aural input that serves as the basis for language acquisition enables learners to interact in spoken communication. Richards (2008) mentioned that language learning depends on listening. From time to time, listening in the senior high school level of education which demanded students to use English in the more communicative way has been a major issue that needs to be taken into consideration. 
Within a few years of the time students pushed to comprehend and to respond the meaning of the text in the form of interpersonal, interactional, special and functional (Kemendiknas, 2016). Usually, the students in the $10^{\text {th }}$ grade were learned to grasp the descriptive, recount, narrative announcement and song. In the grade $11^{\text {th }}$ they practiced to recognize the analytic exposition, explanation, invitation, personal letter, cause and effect, and the song lyrics. Especially at the grade $12^{\text {th }}$, listening becomes more complicated because students were faced the procedure, news item, caption, pictures, photos, suggestion, offer and an idea. All of those text mentioned instructing in the dialogue and the monologue spoken in English.

However, in the real contexts the implementation of the teaching of listening is still far behind the expectation even become a nightmare for both teachers and learners. It is not yet known if many unexpected and inevitable problems happened in almost of the rural and urban school listening classroom. The core problems with it were the issue of costly, inappropriate, unreliable and unavailability of the listening material. Ur (1996) in her preliminary work in this particular field found that when listening learners often find several troubles such as; trouble with sound, word, the natural native speech, lack of real audio to listen, and discouraged in listening classroom.

Moreover, Lie (2007) in her investigation reaches the conclusion that the greatest constraint of the EFL listening in our country was the lack of exposure to the target language. Based on those classical constraints, listening becomes a neglected skill in the field of the teaching of English as a foreign language. As a result, what we concerned about listeners were not only needs a large number of heterogeneous but also an authentic, accessible, reliable, low cost of the listening materials that encourage them to learn listening efficiently.

Nowadays, teachers must be concerned about the pedagogical benefit from the twenty first century technologies. Technology has been demonstrated to facilitate teachers to integrate listening into the sophistication of the multimedia environments. It comes as the brilliant solution to fulfill the need of the target language inputs for the language teaching and learning. Krashen, (1985) was one of the first to accentuate how important the language inputs in the first, second, and foreign language study. Through his comprehensible input theory he proposed that students must receive the language inputs when they were learning the language. One of the major strategy in our knowledge to mediate learners to get many inputs in listening was the use of a wide range of authentic language resources available on the internet that could engage them in their learning process(Erben, Ban, \& Castañeda, 2009).

Many experts have argued that rather than the other sources from the internet podcast can be the most appropriate for the listening. The podcasts were a part of the of the World Wide Web digital products and believed to be an extraordinary source for the language teaching and learning. (Hubbard, 2009) explained that 
podcast offered a hundred of authentic audio and video to listen, so that students can directly connect with the local culture of the language they are studying.

\section{Literature Review}

The podcasts are an innovation of technology for broadcasting audio files and programs on the internet. It's contained of audio which can be listened into the computer, or downloaded to any digital apparatus for later listening. As mentioned by Man Sze (2006), the podcasts were audio and sometime video programs on the web that typically updated its episodes at the regular intervals. As the part of the mobile learning application podcast soon become familiar because of the rapid development of the portable audio, video players and free delivery of digital content on the internet. Moreover, (Basaran \& Cabaroglu, 2014, p.3) stated that podcast was a compound term coined from" iPod and "broadcast" meaning broadcasting via the internet to be played on iPods.

Furthermore, (Putman \& Kingsley, 2009, p. 101) explained that the podcast was from the traditional audio broadcast and transformed into a digital medium similar to a radio show. To sum up, the podcast was the name of a digital recording of a radio broadcast or other similar program released on the websites as MP3 files which are usually uploaded by a particular provider or any other organization at regular interval and can be downloaded into the various digital apparatus such as laptop, gadget, and personal computer and can be heard at any time either inonline or in-offline mode.

The podcasts have famously known and considered to be taking a part in the language teaching and learning because it brings students closer to the target language and has potential to modify the process of the language teaching and learning. The podcast has presented the combination of E-learning audio, video, text files which instantly replaced the using of language laboratories, Compact Disc, Dvd, Radio Cassette that are usually used in the ordinary language classroom. It was notdoes not only makde students to be exposed to many language inputs, but also can stimulate them into the target language because podcast bringseught the nature of the language to occur in the classroom.

In the last few years, some research on the relation between podcast and ELT area were flourished. Hasan \& Tan (2013) performed a study "Podcast Applications in Language Learning". In their investigation they found that podcasts could be great to support nearly all of English language learning skills. Another study related to podcasting also undertaken by Mbah, \& Iloene (2014) entitled "Podcasts for Learning English Pronunciation in Igboland: Students' Experiences and Expectations. They affirmed that learners agreed to the fact that podcast improved their English pronunciation and it also appropriate for the second language learning. Moreover, Gholami \& Mohammadi (2015) in their experiment on "Podcast mediated language learning: levels of podcast integration and developing vocabulary knowledge". They come to the conclusion that there was a significant 
increase in the performance of subjects in the integration of podcasting. The learners who had more contact with mobile learning through podcasting were more motivated to learn the language because they attracted by the glamour of both offline and online services offered.

Furthermore, Patel (2015) in her study "Effectiveness of Podcast to Develop Language Skills of Post Graduate Students". The using of podcast in the English language learning classroom was more beneficial as well as more helpful than the using of the talk and chalk method. On the other side, Faramarzi \& Bagheri (2015), Podcasting: Past Issues and Future Directions in Instructional Technology and Language Learning they suggested that podcasts can be associated into the learning syllabi by considering the content inside it. In relation, (Lawlor \& Donnelly, 2010) asserted that through podcast was expanding learners vocabulary, improve their speaking, listening skill and develop their language comprehension. Mainly, for improving language comprehension skills, the correct chosen of the podcasts that indicated suitable for the level of the learners' were believed to enhance the learner comprehension (Khalili, 2012).

Listening comprehension involved listeners in the process to construct the meaning from what they have listened based on their prior knowledge. (Vandergrift \& Goh, 2012) noted that listening comprehension was an active process occurred on the listeners mind. Moreover, (Hogan, Alonzo \& Adlof, 2014; El-Dali, 2017) highlighted that listening comprehension was the ability to understand what one hears in the purposes of understanding a spoken language. (Gilakjani \& Sabouri, 2011) confirmed that listening comprehension was an active process in which individuals concentrate on selected aspects of aural input, form, meaning of passages, and associate what they have listened to their existing knowledge. In summary, listening comprehension was a complex, active and conscious action in which listeners involved to analyze, interpret and constructing meaning that enabling them to comprehend, understand and give responses to the oral inputs through their ability to discriminate sounds, previous knowledge, grammatical structures, stress, intonation, and the other linguistic or non-linguistic clues.

An interest is an activated attitude that always involves a goal and object. It can be positive attitude toward something that we really like and enjoy or an attitude which continuous accompanist one's attention in choosing an interesting object. An interest is a feeling which determines activities, liking or disliking object that are valued for someone and certain stimulus that leads someone's behavior to particular aims. An interest is a subjective attitude motivating a person to perform a certain task Berlyne (1949). Moreover, Shekhar (2012) mentions that an interest refers to the engagement of someone to something or an activity that he or she prefers. By looking at the definitions above, we come to conclude that the interest is a feeling of what wanting to know or learn about something where someone has a positive attitude towards something he or she really likes and enjoys. In this 
particular study, an interest refers to the feeling and attitude of the students towards podcast in teaching listening comprehension.

The primary objectives of this study were: (1) To investigate whether or not podcast effects on EFL learners listening comprehension, (2) To identify the students' interest towards podcast in teaching listening comprehension. This study employed by the following hypothesis: (1) Null Hypothesis Ho : Podcast does not affect the listening comprehension of the eleventh grade students of SMA Negeri 1 Luwu, and (2) Alternative Hypothesis Ha: Podcast affect listening comprehension of the eleventh grade students of SMA Negeri 1 Luwu.

\section{Research Method}

In order to identify the impact of the podcasts, the method used in this study was a Quan-qual research. This method enables researcher to combine quantitative and qualitative approach in order to make the synergy and strength between the quantitative and qualitative data. Through this research approach, the researcher elaborated in order to be more comprehend a phenomenon fuller than is possible. The quantitative data were collecting first and more heavily weight than the qualitative data Gay, Mills \& Airasian (2012). The quantitative approach was conducted by using of quasi-experimental pretest-posttest design. On the other side, the qualitative approach of this study was conducted by using questionnaire called an open-ended question. The participants of this research were students at the eleventh grades of SMA Negeri 1 Luwu on 2017/2018 academic year. The researcher selected all students in the eleventh grade of the first science department as the experimental group and all students in the eleventh grade of the third science department as the control group by considering the combination of the cluster random sampling and the purposive sampling technique.

In an attempt to collect the data, two kinds of instruments were used namely listening comprehension test and the open-ended question. The listening comprehension test directly adopted from the 2017 English Language National Examination which published by the National Education Standards Agency (BSNP). The test comprises of fifteen multiple-choice questions that need to accomplish in thirty minutes of time. The content of the test were the dialogue, incomplete dialogue, and the monologues divided into four parts of the test. During the test, the students listen to the dialogue, incomplete dialogue, and several monologues and questions spoken in English. Each of its item test spoken twice and after they listen to the dialogue, incomplete dialogue, the monologues, the questions they must respond the five possible answers and decided which one would be the best answer to the question spoken. The open-ended questions consist of six questions which offering many opportunities for students to give a wide range of unexpected comments about the podcasts in the teaching listening comprehension. 
The pre-test conducted in order to measure the prior listening comprehension achievement of the experimental and the control group. Further, The experimental group taught by applying the learnenglishteens.britishcouncil.org/skills/listeningskills-practice- podcast materials which categorized into A2, B1, and B2 in the process of teaching and listening comprehension. This particular level of listening proficiency purely based on the Common European Framework of Reference (CEFR) level descriptors for overall listening comprehension. This global language proficiency level mentioned that the students who on the A2, B1, and B2 were expected to be able to identify, understand, comprehend the general message, get the main point or the specific information about daily activity, narrative spoken in the form of dialogue and monologue (Council of Europe, 2001). Then, the post-test conducted to identify the listening comprehension development after the groups received the different treatment. Finally, the openended question given only for the students in the experimental group in order to explore their interests towards podcast.

In order to analyze the quantitative data several procedures were done. Firstly, the data scored using the formula proposed by Asrul, Ananda \& Rosnita, (2014). Then, it classified into the scales for measuring listening achievement referred to Carrol \& West (1989) as cited in (Flowerdew \& Miller, 2005. p. 208). Next, the statistical package for social sciences (SPSS) version 23 used in order to know the mean score, the standard deviation, frequency, the percentage of the students' scores and to test the hypothesis of significant difference between the mean value in both of the groups on the same independent variable by calculating their value of dependent t-test. On the other side, the qualitative data taken from the openended questions analysed through an open coding technique by identifying, naming, and describing the phenomena based on the data collected Martin \& Turner (1986).

\section{Findings and Discussion}

\section{The students listening comprehension achievement}

The description scale on the table 1 above clearly compares that in the pre-test the experimental and the control group were classified into the same category. Even though, the number of students in each classification was a little bit different. Interestingly, in the post-test result both of the groups were same in listening scale category, however the number of students in the scale was a highly different. It indicates that the listening comprehension achievement in the experimental group significantly increased than in the control group. The most striking result to emerge from the data is hat both of the groups had different achievement after giving treatments.

a. The rate percentage of students listening comprehension 
ELT Worldwide Vol 5 No 2 (2018)

Table 1: The rate percentage of students scores on the pre-test and in the post-test

\begin{tabular}{|c|c|c|c|c|c|c|c|c|c|c|c|}
\hline \multirow{3}{*}{$\begin{array}{c}\text { Percentag } \\
\text { e } \\
\text { Scale }\end{array}$} & \multirow{3}{*}{$\begin{array}{c}\text { Number } \\
\text { Scale }\end{array}$} & \multirow{3}{*}{$\begin{array}{l}\text { Grade } \\
\text { Points }\end{array}$} & \multirow{3}{*}{$\begin{array}{c}\text { Limited } \\
\text { Description } \\
\text { Scale }\end{array}$} & \multicolumn{4}{|c|}{ Pre-Test } & \multicolumn{4}{|c|}{ Post-Test } \\
\hline & & & & \multicolumn{2}{|c|}{ Exp } & \multicolumn{2}{|c|}{ Cont } & \multicolumn{2}{|c|}{$\operatorname{Exp}$} & \multicolumn{2}{|r|}{ Cont } \\
\hline & & & & $\mathbf{F}$ & $\%$ & $\mathbf{F}$ & $\%$ & $\mathbf{F}$ & $\%$ & $\mathbf{F}$ & $\%$ \\
\hline 0 & 0 & $\mathrm{~F}$ & $\begin{array}{l}\text { Non- } \\
\text { Scorable }\end{array}$ & 0 & $0 \%$ & 0 & $0 \%$ & 0 & $0 \%$ & 0 & $0 \%$ \\
\hline $10-30$ & 1 & E & Limited & 18 & $60 \%$ & 28 & $93 \%$ & 2 & $7 \%$ & 19 & $63 \%$ \\
\hline $40-50$ & 2 & D & Adequate & 12 & $40 \%$ & 2 & $7 \%$ & 15 & $50 \%$ & 8 & $27 \%$ \\
\hline $60-70$ & 3 & $\mathrm{C}$ & Good & 0 & $0 \%$ & 0 & $0 \%$ & 11 & $36 \%$ & 2 & $7 \%$ \\
\hline $80-90$ & 4 & B & Very Good & 0 & $0 \%$ & 0 & $0 \%$ & 2 & $7 \%$ & 1 & $3 \%$ \\
\hline 100 & 5 & A & Excellent & 0 & $0 \%$ & 0 & $0 \%$ & 0 & $0 \%$ & 0 & $0 \%$ \\
\hline & & & & 30 & $100 \%$ & 30 & $100 \%$ & 30 & $100 \%$ & 30 & $100 \%$ \\
\hline
\end{tabular}

The deseription seale on the table 1 above elearly compares that in the pre-test the experimental and the control group clascified int the same categry. Even though, the number of students in each classifieation was a little bit different. Interestingly, in the post-test result both of the groups were same in listening scale eategry, however the number of stulents in the seale a highly different. It indieates that the listening omprehension ahievement in the experimental ofoup significantly inereased than in the control group. The most striking result to emerge from the data is hat both of the groups had different achievement after giving o.ton

The mean score and standard deviation of students listening comprehension

The tableTable 2 below reports the difference between the mean score and the standard deviation in pre-test and post-test. Statistically, there was an improvement after each group receiving treatment.

b. achievement

Table 2: The mean score and the standard deviation

\begin{tabular}{clccc}
\hline & Group & N & Mean Score & $\begin{array}{c}\text { Std } \\
\text { Deviation }\end{array}$ \\
\hline \multirow{2}{*}{ Pre } & Experimental & 30 & 34.60 & 9.257 \\
\cline { 2 - 5 } & Control & 30 & 24.26 & 9.269 \\
\hline
\end{tabular}


Post

\begin{tabular}{lccc} 
Experimental & 30 & 54.73 & 12.624 \\
\hline Control & 30 & 37.46 & 13.655 \\
\hline
\end{tabular}

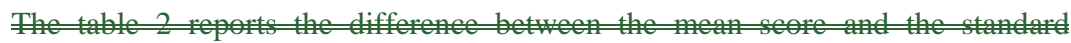

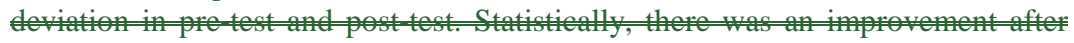

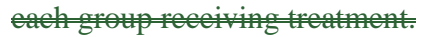

c. Test of significance (T-Test)

c.

t. After calculating the p-value in the experimental and in the control group as shown in the table: 4 were smaller than $\alpha(0.000<0.005)$. Consequently, it indicated that the listening ability of the both groups significantly increased after giving treatments.

Table 3: The Paired Sample Test

\begin{tabular}{lccc}
\hline & P-Value & (a) & Remarks \\
\hline $\begin{array}{l}\text { Pre and Post } \\
\text { of the Experimental } \\
\text { Group }\end{array}$ & 0.000 & 0.000 & $\begin{array}{c}\text { Significantly } \\
\text { Improved }\end{array}$ \\
\hline Pre and Post & 0.000 & 0.000 & $\begin{array}{c}\text { Significantly } \\
\text { Improved }\end{array}$ \\
\hline
\end{tabular}

After ealeutating the $\mathrm{p}$ -

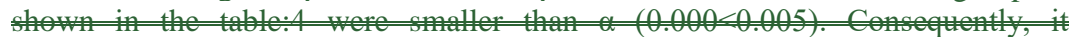
indicated that the listening ability of the both groups signifieantly inereased after ands.

e.d. The Probability Value of the T-Test

Table 4: The Independent Sample T Test

\begin{tabular}{lccc}
\hline & $\begin{array}{c}\text { P-Value } \\
\text { (Sig. 2 tailed) }\end{array}$ & $\begin{array}{c}\text { Level of } \\
\text { Significance } \\
\text { (a) }\end{array}$ & Remarks \\
\hline $\begin{array}{l}\text { Pre-test of the } \\
\begin{array}{l}\text { Experimental Group } \\
\text { and the Control Group }\end{array}\end{array}$ & 0.000 & 0.05 & $\begin{array}{l}\text { There is } \\
\text { significance } \\
\text { differences }\end{array}$ \\
\hline
\end{tabular}

Formatted: Indent: Left: $-0.5 \mathrm{~cm}$, First line: $0 \mathrm{~cm}$

Formatted: Indent: Left: $-0.5 \mathrm{~cm}$, No bullets or numbering

Formatted: Font: (Default) +Headings CS (Times New Roman), 12 pt 
ELT Worldwide Vol 5 No 2 (2018) Rahman, Atmowardoyo, Salija : Podcast Effects on ...

\begin{tabular}{|c|c|}
\hline $\begin{array}{l}\text { Post-test of the } \\
\text { Experimental Groun }\end{array}$ & \\
\hline $\begin{array}{l}\text { Experimental Group } \\
\text { and the Control Group }\end{array}$ & 0.000 \\
\hline
\end{tabular}

As can be seen in the table: 4the p-value outcome of the pre-test and the post-test between the group was 0.000 and the level of significance was 0.05 . In this case, the $\mathrm{p}$-value was smaller than $\alpha(0.000<0.05)$. It shortly explained that, the students' listening comprehension between the groups were different before and after giving treatments.

The results of the hypothesis testing formulated in the experimental group were found that $\mathrm{t}$-value $=4.791$ was higher than $\mathrm{t}$-table $=2.000(\mathrm{p}=0.05, \mathrm{df}=58)$. The comparison between the two values indicated that the $\mathrm{t}$-value was higher than $\mathrm{t}$ table. So, the null hypothesis (Ho) podcast does not affect the listening comprehension of the eleventh grade students of SMA Negeri 1 Luwu rejected while the alternative hypothesis $(\mathrm{Ha})$ podcast affect listening comprehension of the eleventh grade students of SMA Negeri 1 Luwu accepted. The podcast was effective as a supporting medium in learning English listening comprehension. This finding was compatible with the finding of (Fitria, Machdalena \& Ismail, 2015) that there were significant differences in listening achievement between students who taught by using podcasting and the students who taught by using non-podcast.

\section{Students' learning interest towards podcast}

The open-ended questions data were taken from thirty students in the experimental group on March $14^{\text {th }}, 2018$ several days after the last treatment and the post-test given. There were three types of explanations revealed from the qualitative data analysis, covering (1) the strengths, (2) the weaknesses, and (3) the role of the podcast in teaching listening comprehension

Table: 6 The Open-Ended Question Data Analysis

\begin{tabular}{|c|c|c|}
\hline Label & Aspects & Statements \\
\hline The Strength & $\begin{array}{l}\text { 1. New method } \\
\text { in teaching }\end{array}$ & $\begin{array}{l}\text { Very interesting because it was a new thing for us } \\
\text { when it compared } \\
\text { by only doing an exercise on the LKS and } \\
\text { textbook dictation } \\
\text { Listening through podcast was very different } \\
\text { because the previous } \\
\text { way that I used before were writing, translating, } \\
\text { memorizing tenses } \\
\text {, verbs, adjective and noun. } \\
\text { The podcast was very interesting because it is an } \\
\text { amazing method } \\
\text {, different from what teachers have done in the } \\
\text { classroom }\end{array}$ \\
\hline
\end{tabular}


- The podcast in listening class has not only enhanced the ability in listening but also forced our brain to think harder,

2. Challenging and harder

- Podcast in listening was widening our knowledge, adding new vocabulary and trained us with the correct English pronunciation

\begin{tabular}{ll} 
& pronunciation \\
\hline B. Fascinating & $\begin{array}{l}\text { By using podcasts in the classroom the learning } \\
\text { process becomes fun and interesting }\end{array}$ \\
& $\begin{array}{l}\text { Very impressive because it helps to improve } \\
\text { listening ability } \\
\text { and it was different from any other learning } \\
\text { method. }\end{array}$ \\
\hline
\end{tabular}

- The podcast helped me listen to the native

speakers who speak

English very well and it improves my understanding about English correctly

- The podcast was very attractive and cool because it contained many kinds of audio to listen.

4. Very useful

- As long as I learned through a podcast I feel that it's easy to comprehend what I have heard.

- Since the first time I have studied by using podcast I feel it was very difficult for me but after I learned it in many times I feel that's easy easy in listening.

- Very good because it helped us to get the meaning of every word that we have heard.

- Podcast had provided an audio to listen, the transcript to read,

5. Wealthy the exercise to rehearse so we were easy to learn material it.

- Podcast presented many levels of the listening material such as for the beginner, intermediate and advance as well.

- The podcast materials have been available on the internet so if you want to study it is just accessing the site.

6. Availability

- Podcast materials were only needed to download and we can listen to it in offline mode.

- A podcast is easy to access anywhere and we can - download it to listen in it repeatedly

- The podcast was attractive because we can learn in English

7. Futuristic through android devices.

- I love podcasts because I used technology to learn English 
ELT Worldwide Vol 5 No 2 (2018)

Podcast in English class has facilitated us to learn English

I was difficult to get the meaning because I did not familiar

1. Dialect with the British English

Difficulty For me it's difficult to learn because podcast used

- the British dialect and I less familiar with the usage

The Weaknesses

- Rather difficult because this is the first time for me to use podcasting

2. Unfamiliar materials

No, because we rare to use podcasting in learning, most of our time only for reading and writing in our English class

The podcast increasing my listening ability, now I

start

The role on the to understand more about listening in English

listening Improve listening

After I used podcast, my listening ability better

- than before

- By using podcast our listening become very good

Some 30 students completed and returned the open-ended question given and nearly all of them commented that a remarkable fact that the podcast was a highly lucrative application for the teaching of listening comprehension. The Podcast acted as the portable tool and can be accessed through the students smart phone anytime wherever they wish because it is flexible to provide a dynamic environment for learning and making the learning experiences go beyond cross spatial, temporal and conceptual borders. In the same word, the podcast shifted the conventional way of the English language teaching such as do exercise on the students working sheet, writing, dictating textbook, translating, memorizing into the dynamic form.

Working as an authentic materials podcast has presented lots of opportunities to do the meaningful rehearsal and allowing students to hear more about the target language instead of merely doing mechanical drills. Another fact that podcast also forced students to manage their mind to focus on the task, recognizing the new vocabulary, memorizing the sound of the spoken word, and boosting their linguistic competence in order to be a more effective listener. The readiness of its audio files to listen, transcript file to read, the exercises and activities particularly designed for the various levels of student language proficiency were constantly raised students' motivation and willingness to apply their learning styles.

On the contrary, Some fifteen students reported albeit podcast is attracting in the teaching and learning of listening comprehension it could be rather difficult to understand if the students were not familiar in the British English usage, so the teachers were emphasized to adopt the correct chosen of podcast to ensure its efficiency when it utilized as the medium of learning or as an additional language material. 


\section{Conclusion and Suggestion}

This present study has led us to conclude that the podcast had the huge potential to help learners in improving their listening comprehension. The students who learned by using podcasts got a better achievement than those who don't. Moreover, a majority of the students approved that podcast are fascinating in teaching listening comprehension. Students were benefited by podcast because it could become additional materials, even as a medium in the process of teaching and learning of listening. Furthermore, this thing had proved that the using of the podcast was superior than the using of the textbook.

In addition, this study suggests the podcast as the solution to prevent the insufficiency of listening material, so that listening will not be abandoning any more. Teachers can integrate podcast into the related curriculum and the learning syllabi to support them in the teaching of listening. The students are able to use podcasting in order to be more accustom to the spoken English in listening skill and learn it far beyond their language classroom because podcast can also educate them to be an autonomous language learner.

\section{Acknowledgements}

Million thanks to some very important person as follows: the writer supervisors, Prof. Dr. H. Haryanto, M. Pd and Prof. Dr. H. Kisman Salija, M. Pd also as the co-authors of this study for the invaluable encouragement, support, advices, comments and motivation, to the examiners Prof. Dr. Baso Jabu, M. Hum and Prof. Dr. Qashas Rahman, M. Hum for helping in finding the novelty of this article.

\section{REFERENCE}

Asrul, Ananda, R. \& Rosnita(2014) Evaluasi Pembelajaran. Cita pustaka Media. Bandung Başaran, S. \& Cabaroğlu, N (2014). Language

Learning Podcasts and Learners' Belief Change. The Electronic Journal for English as a Second Language, Vol.17(4), 1-32. (Online) Retrieved on April 09th 2018.

Berlyne, D. E. (1949), 'Interest' As A Psychological Concept. British Journal of Psychology.39,184-195.(Online)

(https://onlinelibrary.wiley.com/doi/pdf/10.1111/j.20448295.1949.tb00219.x). Retrieved on May $07^{\text {th }} 2017$.

Council of Europe. (2001). Common European framework of reference for languages: Learning, teaching, assessment. Cambridge,U.K: Press Syndicate of the University of Cambridge.

El-Dali, M. (2017). L2 Listening Comprehension: Is it a Language Problem or Listening Problem? English Linguistics Research,Vol. 6(1),14-37. 
Erben, T., Ban, R., \& Castañeda, M. E. (2009). Teaching English language learners through technology. New York: Routledge.

Faramarzi, S. \& Bagheri, A. (2015). Podcasting: Past Issues and Future Directions in Instructional Technology and Language Learning. Journal of Applied Linguistics and Language Research, Vol. 2(4), 207221.(Online)

Fitria, U., Vianty, M., \& Petrus, I. (2015). Using Podcast To Improve Students'Listening and Speaking Achievements. Journal of English Literacy Education, Vol 2, No 1. Retrieved on April $23^{\text {rd }} 2018$.

Flowerdew, J \& Miller, L. (2005) Second Language Listening Theory and Practice. Cambridge University Press, 40 West 20th Street, New York, NY 10011-4211, USA.

Gay, L. R., Mills, G. E. \& Airasian, P.W (2012). Educational Research. Competencies Analysis and Applications.10thEd. New Jersey: Pearson Education. Inc.

Gholami, M., \& Mohammadi, M. (2015). Podcast- Mediated Language Learning: Levels of Podcast Integration and Developing Vocabulary Knowledge. In Critical CALL - Proceedings of the 2015 EUROCALL Conference, Padova, Italy(pp. 210- 214). (Online) Retrieved on Februari 03rd 2017.

Gilakjani, A. P. \& Sabouri, N. B. (2016). Learners' Listening Comprehension Difficulties in English Language Learning: A Literature Review. English Language Teaching, Vol. 9 (6),123-133. (Online) (http://www.ccsenet.org/journal/index.php/elt/article/view/59636/). Retrieved on July 09th 2017.

Hasan,M., \& Tan, B. H. (2013). Podcast Applications In Language Learning:A Review of Recent Studies. English Language Teaching, Vol.6.(2). pp.128- 135. (Online)

Hogan, P. T, Alonzo, C. N \& Adlof, M. S. (2014). On the Importance of Listening Comprehension. International Journal of Speech-Language Pathology, Vol. 16(3), 199-207. (Online) (https://eps.schoolspecialty.com/EPS/media/Site- Retrieved on January 28th 2018.

Hubbard, P. (2009) Computer Assisted Language Learning:Critical Concepts in Linguistics. Routledge London \& New York. ISBN: 978-0-415-465397.

Kemendiknas(2016). Silabus Mata Pelajaran Bahasa Inggris.Jakarta:Pusat Kurikulum Balitbang Kemendiknas.

Lie, A (2007) Education Policy and EFL Curriculum in Indonesia: Between the Commitment To Competence and the Quest for Higher Test

Scores.TEFLIN Journal, Vol 18,(1),1-14. (Online) (http://teflin.org/journal/index.php/journal/article/viewFile/48/53). Retrieved on November $07^{\text {th }} 2017$. 
Man SZE, P. M, (2006). Developing Students' Listening and Speaking Skills Through ELT Podcasts.Education Journal, Vol.34(2), 115134.(Online) Retrieved on 21st September 2107.

Martin, P. Y. \& Turner, B. A. (1986) Grounded Theory and Organizational Research. The Journal of Applied the Social Behavioral Science, Vol,
22-No,
2 ,
141-157.
(Online) (http://journals.sagepub.com/doi/pdf/10.1177/002188638602200207). Retrieved on May $1^{\text {st }} 2018$

Mbah, E. E., Mbah, B. M. \& Iloene, M. I. (2014).

Podcasts for Learning English Pronunciation in Igboland: Students' Experiences and Expectations. The EUROCALL Review, Vol. 22(2), 57-68. (Online) (https://polipapers.upv.es/index.php/eurocall/article/view/3635). Retrieved on September 03rd 2017.

Patel, A. (2015). Effectiveness of Podcast To Develop Language Skills of Post Graduate Students. International E-Journal for Research in ELT, Vol.1(1), 25-29. Retrieved on February 10th 2017.

Putman, M. S \& Kingsley, T. (2009). The Atoms Family: Using Podcasts To Enhance the Development of Science Vocabulary. The Reading Teacher, International Reading Association, Vol. 63(2),100108.(Online)(http://onlinelibrary.wiley.com/doi/10.1598/RT.63.2.1/pdf ). Retrieved on June 19th 2107.

Richards, J.C. (2008). Teaching Listening and Speaking from Theory to Practice.New York, NY: Cambridge University Press.

Sabet, K. M. (2012). The Impact of Authentic Listening Materials on Elementary EFL Learners' Listening Skills. International Journal of Applied $\begin{array}{llll}\text { Linguistics \& } \quad \text { English 216-229. } & \text { 1(4), }\end{array}$ https://doi.org/10.7575/ijalel.v.1n.4p.216

Shekhar, A. (2012) Pshichology for IAS: Attitudes, Values and Interests.(Online) (https://numerons.files.wordpress.com/2012/0 4/attitudes-values-andinterests.pdf). Retrieved on Spetember $27^{\text {th }} 2107$.

Ur, Penny. (1996). A Course In Language Teaching: Practice and Theory. Williams, M. \& Wright, T. (Ed). UK: Cambridge University Press.

Vandergrift, L., \& Goh, Christine. C. M.(2012). Teaching and Learning Second Language Listening: Metacognition in Action. New York \& London: Routledge,Taylor and Francis. 